\title{
Managing 'Digital China' During the Covid-19 Pandemic: Nationalist Stimulation and its Backlash
}

\author{
Fei Yan $^{1}$
}

Published online: 25 August 2020

(C) Springer Nature Switzerland AG 2020

Keywords China · Covid-19 · Digital information · Nationalism · Legitimacy · Identity

\section{Introduction}

Understanding the management and control of digital information is imperative in modern politics, particularly in authoritarian countries like China where the state keeps a very careful eye out for any information it deems challenging to its legitimacy. As the coronavirus has spread all over the world, China has become the focus of international criticism for its lack of transparency in dealing with its emergence in early stages (Patten 2020). The Chinese people have also questioned their government, yet it is less known how the government's handling of the coronavirus is viewed and evaluated domestically. Chinese traditional media such as newspapers are closely controlled and monitored by the government, so the Internet and social media have become the major arenas of criticism.

Before the pandemic, China's Internet was already one of the most heavily policed in the world. In order to keep ahead of public opinion, the Chinese government has closely 'monitored, guided, censored, and often directly engineered the information that circulates through China's networks' (Schneider 2018: 10). In 2011, China established the Office of Cyberspace Administration of China dedicated to managing the country's digital space. ${ }^{1}$ The Chinese government has come to see the digital world as just another part of its sovereign 'territory,' which needs to be managed and controlled.

Then, how has the Chinese government responded to the voice of the people and what strategies has it adopted in order to deal with the challenges it perceives arising from the digital world? This article examines some of the most hotly debated issues on the Chinese Internet and social media during the Covid-19 pandemic. Analysis shows that the Chinese communist state has updated itself with a 'marriage' between digital technologies and nationalist ideologies, thus gaining the ability to reshape important

${ }^{1}$ http://www.cac.gov.cn. Accessed 5 August 2020.

Fei Yan

fyanedu@163.com

1 South China Normal University, Guangzhou, China 
narratives on the Internet and social media while also having to confront the inevitable backlash from this manipulation.

\section{Managing ‘Digital China’ During the Pandemic}

The coronavirus had begun to spread through China by December 2019 at the very latest. However, most Chinese people were unaware of the growing threat until 20 January when the well-known doctor Zhong Nanshan issued a TV warning of how easily this new virus could be transmitted from person to person. (Zhong had become celebrated in 2003 for his similar warning about the risk of SARS.) Three days after Zhong's TV appearance, the government in Wuhan, where the virus was first detected, announced the lockdown of the city. This decision came as a shock to many Chinese, and while they started to take the issue more seriously, dissatisfaction and anger also proliferated on social media. People criticized the government for lacking transparency and for delaying an official warning. They were especially furious about the fact that the government in Wuhan did not report any new cases of infection between 6 and 17 January when the city was hosting important political events (Daily Mail 2020).

This rising anger among the Chinese populace came to a head on 7 February when the 'whistleblower' Dr. Li Wenliang, an ophthalmologist at a hospital near the Wuhan Seafood Market, died of the virus after becoming infected at work. Great numbers of Chinese people paid tribute to him on social media. The famous lines of 'no man is an island' by the English metaphysical poet John Donne was widely shared on the Internet in reference to $\mathrm{Dr}$. $\mathrm{Li}$, who had become a national hero and a symbol of people's anger over the authorities' initial response to the emergence of the virus (Donne 2019). ${ }^{2}$ Arguably this could have been a moment of hope, a catalyst for change. It was even claimed that Dr. Li's death posed the 'greatest threat' to the Chinese ruling regime (Kate and Martin 2020).

Chinese authorities quickly responded to the clear expression of public anger about the fate of $\mathrm{Dr}$. Li, announcing on the very day of his death that there would be an official police investigation. Subsequently, Dr. Li was officially declared a 'martyr.' Meanwhile, information and theories perceived as critical of the government started to disappear from Chinese social media. From this point, the Chinese government seemed determined to control any narrative which could be perceived as threatening its authoritarian grip on the country (Pendlebury and Naish 2020). New governmentpromoted narratives invoked nationalist ideologies. One clear target of this propaganda was so-called overseas anti-China powers, who had allegedly used the case of Dr. Li to blame China for covering up the virus (Global Times 2020).

The new government narratives resonated easily with the Chinese people, who had long been subjected to political indoctrination through the state-controlled media and schooling system. Scholars of Chinese nationalism and political education point out that in the post-Mao era, and particularly after the Tiananmen Square protest, patriotism had become the ideological cornerstone in Chinese 'thought work,' replacing socialism

\footnotetext{
${ }^{2}$ Several examples of this sharing can be found at: https://dy.163.com/article/F4SCIUQ40517N5H8.html, https://www.bilibili.com/read/cv4596613/, and https://www.520595.com/article/article_2698.html?page_p=1. Accessed 18 July 2020.
} 
(He and Guo 2000; Hughes 2006; Vickers 2009; Zhao 2004). This involved highlighting the 'one hundred years of humiliation' that China had suffered at the hands of the Western imperialist powers since the time of the Opium Wars (1840) and the resulting collective sense of 'victimhood' from that humiliation (Mitter 2003). When China ended up under increasing pressure from the international community because of its mishandling of the virus, the government sought to stimulate nationalist sentiment and chose to re-interpret criticisms from other countries as a new form of imperialism. As a result, any criticism by the Chinese people of their own government over the handling of the pandemic is regarded as 'handing over knives' to enemies and hence becomes 'unpatriotic' (Davidson 2020).

The effect of this strategy soon appeared in another major Internet-fueled controversy_-Fang Fang's Wuhan Diary. Fang is a Wuhan-based novelist who started to sympathetically document the difficulties of the city's inhabitants under the sudden lockdown. In spite of constant official censorship, millions followed her account online as she revealed her mounting frustration with the officials. Fang's online diaries presented an unwelcome challenge to the state narrative, which by this time was concentrated on promoting the triumphs of the Chinese government in winning the war against the virus and contrasting its success with its 'failing' Western counterparts who were presented as struggling ineffectually to combat the spread of the pandemic.

An Internet propaganda campaign was duly mounted, with the clear aim of vilifying and demonizing Fang. She was denounced by an online army of ultra-nationalists for 'betraying the motherland' (Davidson 2020), particularly when her diaries were published in English under the title Wuhan Diary: Dispatches from a Quarantined City (Fang 2020). Many ordinary people were persuaded that Fang was indeed a traitor. Fang and her English translator were the subject of death threats (Ehret 2020; Feng 2020). Academics who had supported Fang on social media were abused and subsequently placed under official investigation for 'making inappropriate remarks' about China (Shepherd 2020). At the time of writing, one of these academics (Liang Yanping) had been banned from teaching by her university (Zhuang 2020).

\section{Backlash Against Nationalist Manipulation}

While ideological tools such as nationalism are indeed very useful in manipulating online discourse, it appears that Chinese officials have possibly underestimated its unexpected negative consequences. This state-sponsored 'reprogramming' has seemingly instilled in people an ill-thought-out ideology based on fear and ultra-patriotism which 'creates all manner of domestic and international contradictions' (Schneider 2018: 229). For instance, Chinese students studying abroad were refused permission to re-enter China after their places of study had become epicenters of the virus. In the early days of the pandemic, many of these students had previously done their very best to help their native country by gathering and posting masks and other protective equipment back home. Rather than expressing sympathy for these students, many people on the Chinese Internet blamed them for exposing China to the risk of a second wave of the virus, and some were hostile to their choice of studying abroad as they believed this demonstrated a future intent to betray China (Li 2020). 
This issue caused huge public controversy and great distress to the students themselves - followed by an enormous amount of confusion for students and their families, who had believed the nationalist propaganda that 'Your motherland will always be there to protect you when you are in danger overseas' (Stevenson and May 2020). ${ }^{3}$ Ironically, many Chinese students studying overseas are in fact hyperpatriotic in defending their country abroad (He 2015). Yet incidents such as this, fueled by the accusatory propaganda on social media, may just be prompting them to reflect upon their previous assumptions, rethink their identity as patriotic citizens, and reexamine their relationship with the Chinese state which seemed to have turned its back on them in the time of need.

A further issue has been the unfortunate association of Chinese nationalism with the racial aspect of Chinese identity (Dikötter 1992). Chinese officials often claim that racism is a Western phenomenon, yet racial discrimination against other ethnic groups, and black people in particular, has been exacerbated during the Covid-19 pandemic (HRW 2020). Chinese people have come to fear that African immigrants could be spreading the virus, and there is evidence that black people in China have been treated in a most unpleasant and discriminatory manner. For example, social media videos showed some black people in Guangzhou (which has a sizeable African population) being expelled from their residences, and others 'who appear to be of African origin' were banned from entering restaurants such as McDonalds (Deabler 2020). Damning accusatory rumors circulated on social media such as ' 300,000 black people in Guangzhou are setting off a second epidemic' along with comments like 'the blacks are an inferior race,' 'use the opportunity of the epidemic to kick the blacks out,' and 'do not let them stain the Chinese race' (Deabler 2020). Consequently, tensions between native Chinese and African immigrants in Guangzhou have naturally became inflamed.

And there are further unfortunate consequences. When the unfair treatment of African immigrants and the use of racist language were reported back to their countries of origin, there was an inevitable fierce backlash against Chinese officials (Burke et al. 2020). On the other hand, when Chinese citizens saw social media videos showing Chinese officials being blamed by diplomats of African countries (who are China's important strategic partners of the Belt and Road Initiatives) (HRW 2020), some Chinese citizens, infected with nationalist propaganda, blamed their government for being 'too soft on foreigners' and reducing its own people to 'second-class citizens.' In this and other ways, identity games with ill-conceived concepts of racism under the umbrella of nationalism have backfired on the Chinese government.

\section{Conclusion}

While the Internet and social media have provided the Chinese people with the means to express and exchange their ideas more easily, these technological opportunities have not promoted a 'Habermasian Public Sphere' which could facilitate China's transition to a liberal, democratic system of government (Schneider 2018: 11). Instead, the

\footnotetext{
${ }^{3}$ This quote is from the popular Chinese nationalist movie Wolf Warrior II, a 'Rambo'-like Chinese blockbuster featuring a patriotic soldier from the People's Liberation Army protecting Chinese people from overseas threats.
} 
Chinese government has taken their overarching model of media management and has creatively extended it to its digital world (Schneider 2018: 24). The Chinese state has used up-to-date digital technology to control the content of its Internet output by managing narratives which promote its political agenda. By being the most powerful player in China's digital world, the ruling regime has managed to simultaneously deploy 'hard' power (censorship) and 'soft' power (reshaping public opinion by promulgating ideologies such as nationalism) to manage and control 'digital China.' The Chinese state is employing its digital skillset to control its citizens, rather than the other way around.

\section{References}

Burke, J. et al. (2020). China fails to stop racism against Africans over Covid-19. The Guardian, 27 April. https:/www.theguardian.com/world/2020/apr/27/china-fails-to-stop-racism-against-africans-over-covid19. Accessed 18 July 2020.

Daily Mail. (2020). The coronavirus facts China wants the world to forget: Beijing releases a COVID-19 timeline - but fails to include whistle-blowers, Huanan food market and 'the order to destroy all samples'. Daily Mail, 8 April. https:/www.dailymail.co.uk/news/article-8196515/The-coronavirus-facts-Chinawants-world-forget.html. Accessed 10 June 2020.

Davidson, H. (2020). Chinese writer faces online backlash over Wuhan lockdown diary. Guardian, 10 April. https://www.theguardian.com/world/2020/apr/10/chinese-writer-fang-fang-faces-online-backlash-wuhanlockdown-diary. Accessed 10 June 2020.

Deabler, A. (2020). McDonald's in China apologizes for notice banning black customers from entering restaurant. Fox News, 14 April. https://www.foxnews.com/food-drink/mcdonalds-china-apologizingnotice-banning-black-people. Accessed 10 June 2020.

Dikötter, F. (1992). The discourse of race in modern China. Hong Kong: Hong Kong University Press.

Donne, J. (2019). Devotions upon emergent occasions: Together with death's dual. Chalemette: Parables.

Ehret, L. (2020). Chinese writer Fang Fang faces backlash and death threats for 'Wuhan diary'. AFP, 23 April. https:/hongkongfp.com/2020/04/23/chinese-writer-fang-fang-faces-backlash-and-death-threats-forwuhan-diary/. Accessed 10 June 2020.

Fang, F. (2020). Wuhan diary: dispatches from a quarantined city. Trans. M. Berry. New York: HarperCollins.

Feng, E. (2020). Wuhan diary' brings account of China's coronavirus outbreak to English speakers. National Public Radio,14 May. https:/www.npr.org/2020/05/14/855122795/wuhan-diary-brings-account-ofchinas-coronavirus-outbreak-to-english-speakers. Accessed 18 July 2020.

Global Times. (2020). Taking Li's death as a tool to stir up anti-govt sentiment on Chinese social media is part of overseas separatists' customary tactics, as they used in \#HK protest. Such move is obnoxious and childish, said experts. Twitter of the global times (a nationalist mouthpiece of the Chinese government), 8 February. https://twitter.com/globaltimesnews/status/1226143714365595649. Accessed 18 July 2020.

He, R. X. (2015). Identifying with a "rising China"? Overseas Chinese student nationalism. In E. Vickers \& K. Kumar (Eds.), Constructing modern Asian citizenship. Oxford and New York: Routledge.

He, B., \& Guo, Y. (2000). Nationalism, national identity and democratization in China. Aldershot: Brookfield USA: Ashgate.

HRW. (2020). China: Covid-19 discrimination against Africans. Human rights watch, 5 May. https://www. hrw.org/news/2020/05/05/china-covid-19-discrimination-against-africans. Accessed 18 July 2020.

Hughes, C. (2006). Chinese nationalism in the global era. London: Routledge.

Kate, D. T., \& Martin, P. (2020). The death of a doctor poses the greatest threat to China's Xi yet. Bloomberg, 13 February. https://www.bloomberg.com/news/articles/2020-02-13/the-death-of-a-doctor-poses-thegreatest-threat-to-china-s-xi-yet. Accessed 13 June 2020.

Li, Y. (2020). Trapped abroad, China's 'little pinks' rethink Their Country. The New York Times, 24 June. https://www.nytimes.com/2020/06/24/business/china-nationalist-students-coronavirus.html. Accessed 18 July 2020.

Mitter, R. (2003). Old ghosts, new memories: China's changing war history in the era of post-Mao politics. Journal of Contemporary History, 38(1), 117-131. https://doi.org/10.1177/2F0022009403038001967. 
Patten, C. (2020). "China's nasty, lying, bullying Communist regime must face the judgment of the world over the coronavirus pandemic". Daily Mail, 9 May. https:/www.dailymail.co.uk/debate/article-8303719 /LORD-PATTEN-Chinas-nasty-lying-bullying-Communist-regime-face-judgment-coronavirus.html. Accessed 18 July 2020.

Pendlebury, R., \& Naish, J. (2020). China's deadly legacy: The coronavirus cover-up was one of the most grotesque deceptions by a totalitarian government ever - now Beijing will use the pandemic it sparked to help achieve its goal as Nol world superpower. Daily Mail, 18 April. https://www.dailymail.co. uk/news/article-8231467/Chinas-deadly-legacy-exposed-Major-new-series-sorts-coronavirus-conspiracytheories-facts.html. Accessed 10 June 2020.

Schneider, F. (2018). China's digital nationalism. Oxford: Oxford University Press.

Shepherd, C. (2020). Fang Fang's ‘Wuhan diary’ sparks tussle over virus narrative. Financial Times, 15 May. https://www.ft.com/content/fc18c38d-bca8-4cd8-b542-f526259d97fd. Accessed 18 July 2020.

Stevenson, A., \& May, T. (2020). Coronavirus strands China's students, in a dilemma for Beijing, The New York Times, 5 April. https://www.nytimes.com/2020/04/05/world/asia/coronavirus-china-students.html. Accessed 18 July 2020.

Vickers, E. (2009). The opportunity of China? Education, patriotic values and the Chinese state. In M. Lall \& E. Vickers (Eds.), Education as a political tool in Asia. London: Routledge.

Zhao, S. (2004). A nation-state by construction: Dynamics of modern Chinese nationalism. Stanford: Stanford University Press.

Zhuang, P. (2020). Chinese professor banned from teaching over Hong Kong protest comments, South China Morning Post, 20 June. https:/www.scmp.com/news/china/politics/article/3089929/chinese-professorbanned-teaching-over-hong-kong-protest. Accessed 18 July 2020. 